\title{
LOGAM DALAM EKOSISTEM PERAIRAN
}

\author{
Reny Puspasari") \\ Peneliti pada Pusat Riset Perikanan Tangkap. Ancol-Jakarta
}

\begin{abstract}
ABSTRAK
Logam berat dalam air dapat termasuk ke dalam bahan berbahaya dan beracun bila ditemukan dalam konsentrasi tinggi. Pada konsentrasi rendah logam dibutuhkan oleh organisme hidup untuk pertumbuhan dan perkembangan, namun bila kadar meningkat maka logam akan berubah menjadi racun. Ada 2 mekanisme masuk logam berat ke dalam tubuh mahluk hidup, yaitu melalui proses penyerapan dan melalui rantai makanan. Banyak pengaruh negatif yang ditimbulkan apabila logam berat berada dalam konsentrasi tinggi dalam tubuh, misal menghambat laju fotosintesis, merubah bentuk sel, memperkecil ukuran sel, menghambat laju pertumbuhan, dan yang paling fatal adalah menyebabkan kematian. Berdasarkan pada hasił penelitian yang dilakukan, kandungan logam berat dalam tubuh mahluk hidup ditentukan oleh konsentrasi logam berat terlarut dalam air dan oleh kandungan agen pengikat logam berat dalam tubuh mahluk hidup tersebut. Kandungan karbohidrat, protein, dan lemak menjadi agen yang berperan penting dalam proses pengikatan logam berat.
\end{abstract}

KATA KUNCI: logam berat, ekosistem perairan, agen pengikat

\section{PENDAHULUAN}

Kasus pencemaran perairan oleh logam berat berbahaya dan beracun seringkali terjadi. Tidak jarang pula menimbulkan korban yang cukup serius, baik manusia maupun organisme lain penghuni ekosistem perairan. Namun, kehadiran cemaran logam berat dalam ekosistem perairan seolah tidak dapat dihindari.

Apabila mendengar kata logam, maka yang terbayang di benak kita adalah benda-benda keras yang berkilauan, seperti emas, perak, besi, baja, dan kuningan. Ternyata bila dipelajari lebih jauh dengan melihat sistem berkala periodik unsur-unsur, yang termasuk ke dalam golongan logam tidak hanya zatzat yang bertekstur keras dan berkilauan, tetapi ada juga zat-zat yang bertekstur lembut namun digolongkan sebagai logam. Dalam sistem berkala periodik unsur-unsur, 94 dari 106 unsur yang ada di alam adalah logam. Berdasarkan pada bobot atom logam dapat dibedakan menjadi 2 yaitu logam berat dan logam ringan. Menurut Proteous (1991) logam berat adalah logam yang mempunyai bobot atom besar, definisi lain logam berat sebagai logam yang mempunyai bobot $5 \mathrm{~g}$ atau lebih setiap $\mathrm{cm}^{3}$. Hal ini, berarti 5 kali lebih besar dari bobot jenis air, misa merkuri $(\mathrm{Hg})$, timbal $(\mathrm{Pb})$, dan cadmium (Cd). Sementara itu, logam ringan yaitu logam yang bobot atom lebih kecil dari $5 \mathrm{~g}$ per $\mathrm{cm}^{3}$ contoh natrium ( $\mathrm{Na}$ ) dan kalium (K).

Dalam jumlah kecil logam diperlukan oleh mahkluk hidup untuk proses kehidupan, termasuk untuk pertumbuhan dan perkembangan. Dalam peran di tubuh mahluk hidup logam dibedakan menjadi 2 jenis. yaitu logam yang peranan nyata dalam proses metabolisme tubuh disebut logam esensial dan logam non esensial yang peranan belum banyak diketahui dalam tubuh mahluk hidup. Kandungan logam dalam tubuh sangat kecil dan bila berada dalam jumlah yang berlebihan dapat menimbulkan kerusakan organorgan tubuh organisme yang bersangkutan

\section{SUMBER LOGAM DI PERAIRAN}

Logam di alam berasal dari berbagai sumber antara lain proses tektonik, vulkanik, up welling, masukan dari atmosfer, dan masukan dari daratan. Masukan dari daratan mempunyai peranan terbesar dalam meningkatkan konsentrasi logam berat di perairan, salah satu akibat buangan limbah cair industri.

Secara alamiah, logam sudah terdapat dalam air laut, tetapi dalam jumlah yang sangat kecil, menurut penelitian yang dilakukan oleh Hutagalung (1997), kandungan logam berat dalam air laut berkisar antara $10^{-5}$ sampai dengan $10^{2} \mathrm{ppm}$. Konsentrasi logam berat dalam air sangat bervariasi, salah satu bergantung pada musim. Pada musim penghujan saat curah hujan tinggı, banyak logam berat baik dalam bentuk terlarut atau endapan yang terbawa dari darat ke laut melalui aliran surigai.

Keberadaan logam berat dalam air dapat ditemukan dalam berbagai bentuk yaitu terlarut, endapan, atau butiran halus. Logam berat terlarut lama kelamaan akan mengendap, tetapi membutuhkan waktu yang cukup lama (Hutagalung \& Manik, 2002; Rochyatun E., 1997). 


\section{LOGAM BERAT DALAM SISTEM BIOLOGI AQUATIK}

Pada konsentrasi rendah logam dibutuhkan oleh organisme hidup untuk pertumbuhan dan perkembangan, namun bila kadar meningkat, maka logam akan berubah menjadi racun

Ada 2 mekanisme masuk logam berat ke dalam tubuh mahluk hidup, yaitu secara langsung dan tidak langsung. Mekanisme langsung terjadi melalui penyerapan logam berat terlarut oleh organisme yang melakukan proses penyerapan air dan nutrien ke dalam tubuh. Pada umumnya mekanisme ini berlaku pada tumbuhan air, yang menyerap unsur-unsur hara untuk proses metabolisme, melalui proses difusi osmosis. Cara lain logam berat dapat masuk ke dalam tubuh organisme hidup adalah melalui rantai makanan.

Dalam proses makan-memakan, terjadi transfer bahan dan energi dari organisme yang dimangsa ke organisme pemangsa. Dalam susunan rantai makanan, yang menjadi awal dari kegiatan tersebut adalah tumbuhan yang berperan sebagai produsen. Produsen dalam proses seianjutnya akan dimakan oleh konsumen tingkat 1 , konsumen tingkat 1 akan dimakan oleh konsumen tingkat 2, dan seterusnya. Gambaran rantai makanan dalam ekosistem perairan dapat dilihat pada Gambar 1.

Produsen mempunyai kemampuan dalam menyerap dan mengakumulasi logam berat dalam sel. Apabila kelompok produsen ini dimangsa oleh konsumen pada tingkat trofik selanjutnya, maka akan terjadi transfer logam berat tersebut ke dalam tubuh konsumen tingkat 1 . Transfer logam berat akan terus berlangsung sampai dengan ke tingkat trofik tertinggi. Semakin tinggi tingkatan trofik; maka akumulasi logam berat dalam tubuh akan semakin banyak. Hal ini, berkaitan dengan biomassa mangsa dan panjang rantai makanan.
Tumbuhan air atau fitoplankton sebagai produsen primer tidak selektif dalam memilih jenis unsur yang akan diserapnya. Karena ada proses penyerapan logam ini, pada umumnya kandungan logam di lingkungan sampai dengan taraf tertentu akan sebanding dengan kandungan logam dalam sel organisme yang hidup di lingkungan tersebut. Berdasarkan pada hasil penelitian Kelly \& Whitton (1989) yang melakukan perbandingan akumulasi $\mathrm{Zn}$, $\mathrm{Cd}$, dan $\mathrm{Pb}$ pada beberapa jenis alga air tawar dan Bryophyta menunjukan bahwa pada alga Lemanea fluviatilis (Rhodophyta) dan Cladophora glomerata (Chlorophyta) terdapat hubungan positif antara kadar logam berat dalam air dan dalam tubuh organisme, dengan nilai koefisien determinasi $\left(r^{2}\right)$ untuk kondisi total dalam perairan adalah 0.66 untuk Lemanea dan 0,61 untuk Cladophora kecuali Stigeoclonium tenue, tidak menunjukkan ada hubungan positif untuk logam berat $\mathrm{Cd}$ dan $\mathrm{Pb}$ (Gambar 2). Ditambahkan pula bahwa terdapat hubungan yang berbeda-beda antara spesies dan jenis logam berat.

Apabila jumlah toksikan yang masuk ke dalam sel sangat banyak, dan tidak dapat lagi terikat pada agen pengikat, maka sifat toksik tidak dapat dinetralkan oleh sel tersebut. Akibat adalah terjadi kerusakkan pada sistem tubuh organisme tersebut. Gangguan yang terjadi adalah penghambatan laju pertumbuhan dan perkembangan, kelainan dalam bentuk se! atau organel sel dan merusak fungsi organel sel.

Penelitian lain yang dilakukan oleh Effendi (1995), mengenai pengaruh logam berat $\mathrm{Cd}$ dan $\mathrm{Cu}$ terhadap Scenedesmus armatus (mikroalgae) mengatakan bahwa kehadiran $\mathrm{Cd}$ dan $\mathrm{Cu}$ dalam kultur Scenedesmus armatus dapat menghambat laju fotosintesis sel dan menyebabkan terjadi perubahan ukuran sel tersebut. Dari hasil penelitian didapat bahwa pada konsentrasi $0,6 \mathrm{mg}^{1}{ }^{1} \mathrm{Cd}$ terjadi penurunan densitas dan absorban dari sel secara lebih nyata dari konsentrasi di bawah

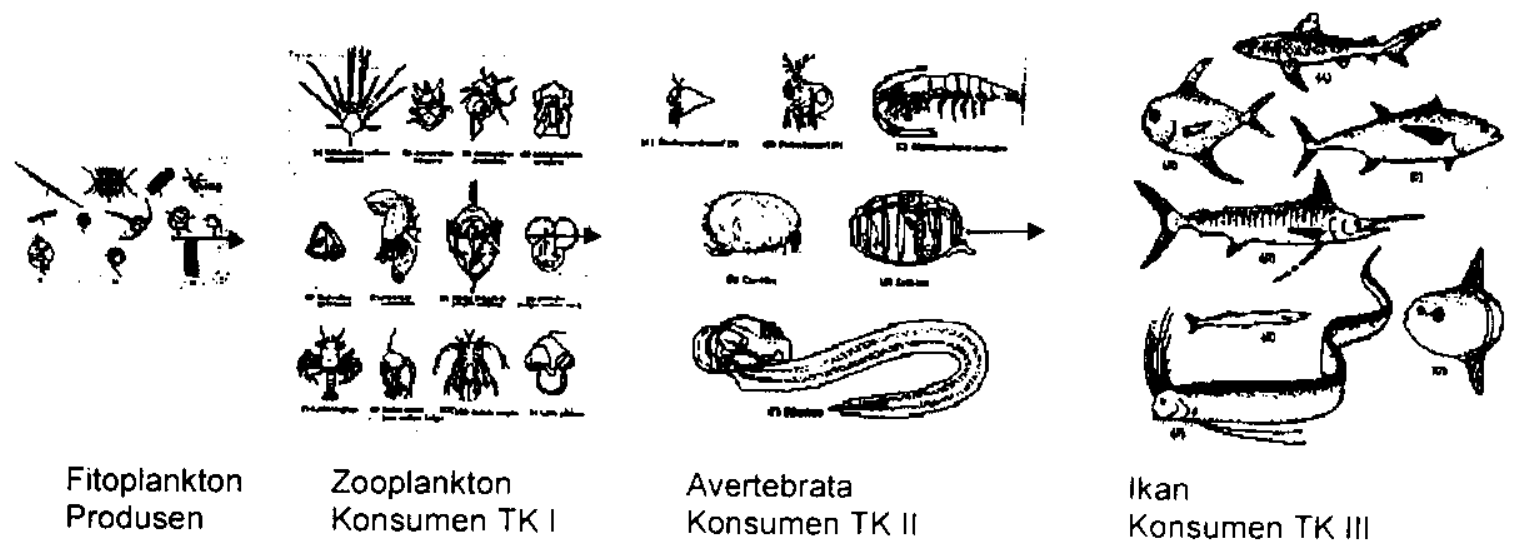
Gambar 1. Rantai makanan dalam ekosistem aquatik sebagai salah satu mekanisme transfer logam berat.
Sumber/Sources: Nybaken, 1992 


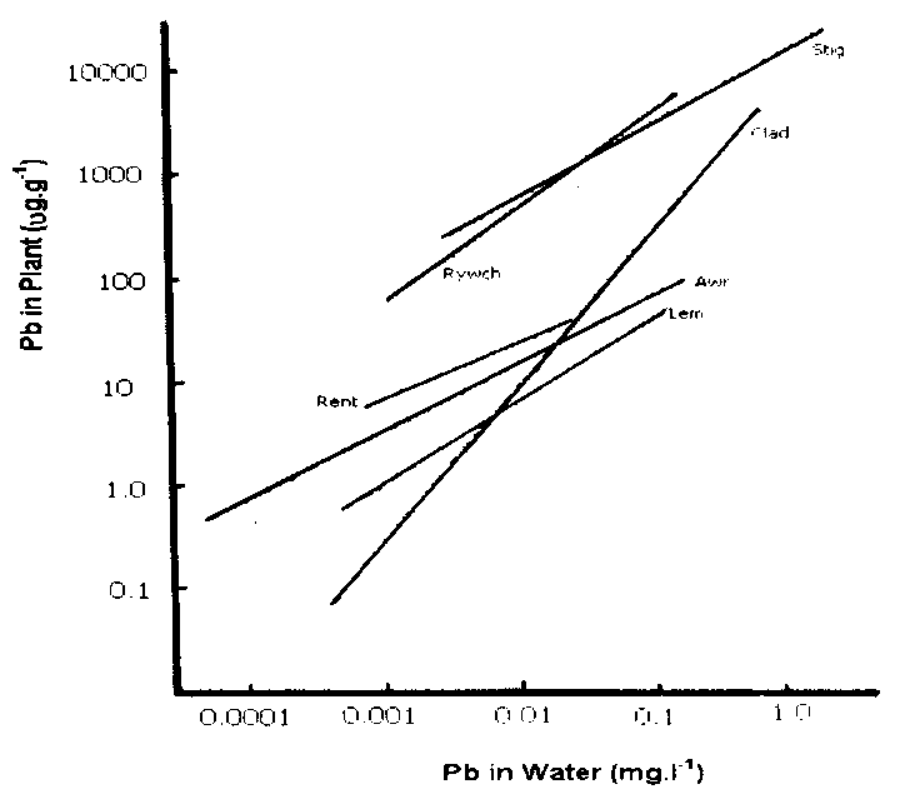

Gambar 2. Pengaruh $\mathrm{Pb}$ dalam air terhadap kandungan $\mathrm{Pb}$ dalam tubuh alga dan Bryophyta. Sumber/Sources: Kelly \& Whitton, 1989

Penulis melakukan uji coba untuk melihat pengaruh keberadaan logam berat $\mathrm{Pb}$ terlarut dalam air, terhadap kandungan chlorofil 2 jenis mikroaiga yaitu Dunaliella salina dan Chaetoceros calcitrans. Dari hasil penelitian didapat bahwa kadar $\mathrm{Pb}$ terlarut lebih dari $0.1 \mathrm{ppm}$ dapat menyebabkan gangguan terhadap laju penambahan jumlah klorofil sehingga berakibat pada penurunan iaju pertumbuhan sel. Pada konsentrasi yang tinggi inkubasi sel yang cukup lama dapat menyebabkan kerhatian karena efek toksik yang sudah tidak dapat dinetralkan lagi, dan dengan banyak kematian sel menyebabkan biomassa klorofil per satuan bobot basah sel menjadi berkurang. Perbedaan respon ke-2 spesies uji terhadap berbagai konsentrasi $\mathrm{Pb}$ terlarut dalam air dapat dilihat pada grafik Gambar 3.
Setiap jenis mahluk hidup mempunyai kemampuan spesifik dalam mengakumulasi logam berat. Kemampuan mengakumulasi logam berat ini berhubungan dengan banyak jumlah agen pengikat logam berat dalam tubuh. Daging, darah, cairan sendi, dan rambut menjadi tempat di mana logam berat terikat dalam tubuh. Kandungan karbohidrat, protein, dan lemak menjadi agen yang berperan penting dalam proses pengikatan tersebut. Dari hasil penelitian penulis, salah satu faktor yang mempengaruhi penyerapan logam berat oleh mikroalgae adalah kandungan protein, karbohidrat. dan lemak.

D. salina yang memiliki kandungan protein, lemak, dan karbohidrat yang lebih tinggi daripada $C$.

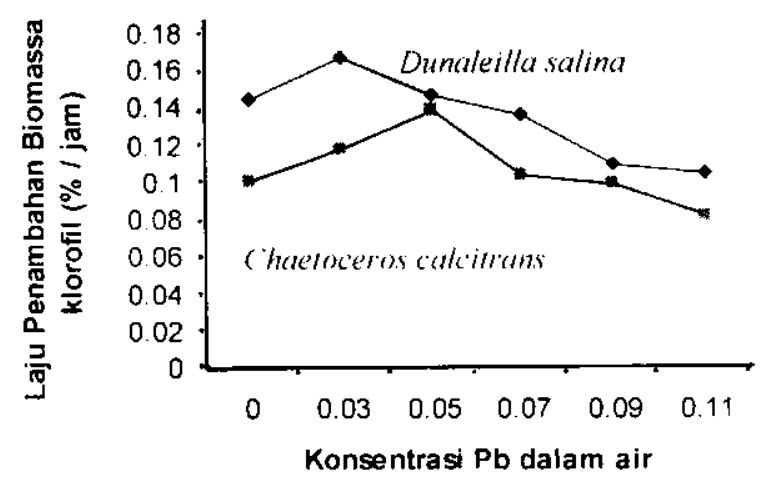

Gambar 3. Laju pertumbuhan spesifik 2 jenis fitoplankton terhadap pemaparan Po dengan berbagai konsentrasi.

Sumber/Sources: Puspasari, 2000 
Tabel 1. Kandungan protein, lemak, dan karbohidrat pada Dunaliella salina dan Chaetoceros calcitrans (ppm)

\begin{tabular}{|c|c|c|c|}
\hline $1800-48$ & $80 \mathrm{tel}$ & 40121 & raponor \\
\hline Dunaliella salina & 43.06 & 3.5 & 4.11 \\
\hline Chaetoceros calcitrans & 21.55 & 1.93 & 2.73 \\
\hline
\end{tabular}

Sumber/Sources: Puspasari et al. 2000

calcitrans, mempunyai kemampuan menyerap logam berat yang lebih tinggi daripada $C$. calcitrans (Tabel 1) (Puspasari et al., 2000)

Akumlasi logam berat pada organisme yang berperan sebagai konsumen terjadi melalui ke-2 mekanisme di atas, yakni secara langsung dan tidak langsung. Kerang-kerangan merupakan contoh yang mudah untuk dilihat. Kelompok hewan ini mempunyai kemampuan yang tinggi untuk mengakumulasi logam berat dalam tubuh. Dengan sifat makan sebagai filter feeder, kerang-kerangan menyaring fitoplankton dari air laut melalui mulut. Logam berat terlarut dalam air laut yang masuk ke tubuh kerang dapat langsung ikut terserap oleh agen pengikat, dan logam berat yang terikat dalam sel fitoplankton pun ikut terakumulasi dalam jaringan tubuh.

Kerang-kerangan dan organisme bentuk lain dijadikan indikator untuk melihat apakah suatu perairan tercemar logam berat atau tidak. Organisme bentuk yang hidup di dasar perairan mempunyai kemampuan mengakumulasi kandungan logam berat yang tinggi, hal ini berkaitan dengan tinggi kadar logam berat dalam sedimen bila dibandingkan dengan logam berat terlarut dalam air.

Perairan dengan beban masukan sungai yang tinggi seperti di Teluk Jakarta akan mempunyai kandungan logam berat yang tinggi. Berdasarkan pada hasil penelitian yang dilakukan oleh Pusat Penelitian Oseanologi-Lembaga Ilmu Pengetahuan Indonesia, perairan Teluk Jakarta dinyatakan telah terkontaminasi oleh logam berat $\mathrm{Pb}, \mathrm{Cd}, \mathrm{Cu}$, dan $\mathrm{Zn}$. Kadar ke-4 jenis logam berat tersebut dalam sedimen sudah melebihi ambang batas standar. Tabel 2 menjelaskan kandungan logam berat dalam sedimen di perairan Teluk Jakarta.

Ekosistem perairan sangat berbeda dengan ekosistem terestrial, ekosistem perairan disatukan oleh media air, di mana fitoplankton menjadi produsen primer. Keberadaan fitoplankton yang sangat melimpah tidak dapat dihilangkan dari suatu perairan. Media air menjadi pemersatu antar wilayah, arus yang berperan penting dalam penyebaran segala sesuatu yang terkandung di dalam. Dengan kondisi yang demikian sangat sulit untuk memutus jalur penyebaran logam berat di alam sistem perairan

Kondisi seperti ini menjadi suatu tantangan bagi para peneliti untuk mencari teknologi mengurangi kandungan logam berat dalam sistem perairan. Sampai saat ini, logam berat berbahaya dan beracun yang masuk ke dalam ekosistem perairan dibiarkan apa ada, sampai dengan proses alamiah yang mengubah

Tabel 2. Kadar logam berat dalam sedimen perairan Teluk Jakarta

\begin{tabular}{|c|c|c|}
\hline benis rogantretat. & 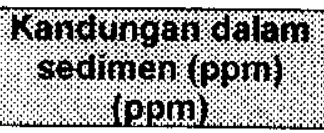 & 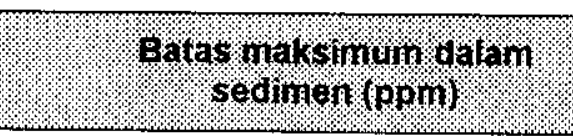 \\
\hline $\mathrm{Pb}$ (Timbal) & $14,15-23,76$ & 0,01 (Moore \& Ramamoorthy, 1984) \\
\hline Cd (Cadmium) & $0,03-0,06$ & 0,01 (Moore \& Ramamoorthy, 1984) \\
\hline Cu (tembaga) & $15,34-19,02$ & 5,00 (RNO) $^{*}$ \\
\hline $\mathrm{Zn}($ Zinc) & $86,69-114,94$ & $20-150(\mathrm{RNO})^{\star}$ \\
\hline
\end{tabular}

Keterangan/Remarks: *RNO = Reseau National d'Observation

Sumber/Sources: P2O LIPI (2003)

\section{KESIMPULAN}

1. Logam di perairan berasal dari berbagai sumber antara lain proses tektonik, vulkanik, up welling. masukan dari atmosfer dan masukan dari daratan.
2. Ada 2 mekanisme masuk logam berat ke dalam tubuh mahluk hidup, yaitu secara langsung melalui penyerapan nutrien ke dalam tubuh mahluk hidup dan tidak langsung melalui transfer bahan dan energi dari organisme yang dimangsa ke organisme pemangsa. 
3. Konsentrasi logam berat dalam tubuh biota dipengaruhi oleh konsentrasi logam berat terlalut dalam air dan konsentrasi agen pengikat logam berat dalam tubuh biota tersebut.

4. Pengaruh logam berat dalam konsentrasi berlebih dalam air dapat menimbulkan terjadi perubahan bentuk sel, menghambat laju fotosintesis, menghambat pertambahan jumlah klorofil dan menghambat laju pertumbuhan.

5. Teluk Jakarta dinyatakan telah terkontaminasi oleh logam berat $\mathrm{Pb}, \mathrm{Cd}, \mathrm{Cu}$, dan $\mathrm{Zn}$.

\section{DAFTAR PUSTAKA}

Moore, J. W. \& S. Ramanoorthy. 1984. Heavy metals in natural waters. Springer-Verlag. USA.

Effendi, Hefni. 1995. Abnormal shape and size of scenedesmus armatusl as indicator of cooper and cadmium pollution. Jurnal llmu-llmu Perairan dan Perikanan Indonesia. Vol. III (2): 51-70.

Rochyatun, E. 1997. Pemantauan kadar logam berat ( $\mathrm{Pb}, \mathrm{Cd}$, dan $\mathrm{Cr}$ ) dalam sedimen di muara Sungai Dadap. Inventarisasi dan Evaluasi Potensi Laut Pesisir II. Pusat Penelitian Oseanologi. Lembaga Ilmu Pengetahuan Indonesia

Puspasari R., R. Kaswadji, \& H. Sanusi. 2000. The capability of phytoplankton in reducing heavy metal $\mathrm{pb}$, concentration in sea water. Proceedings of The JSPS DGHE International Symposium on Fisheries Science in tropical Area. Bogor.
Hutagalung, $H$ \& Jack Manik. 2002. Kandungan logam berat dalam air, dan sedimen di perairan muara Sungai Digul dan Arafura. Jurnal Pesisir dan Pantai Indonesia VII. Pusat Penelitian Oseanologi. Lembaga IImu Pengetahuan Indonesia.

Hutagalung, H. 1997. Penentuan kadar logam berat. Metode analisis air laut, sedimen, dan Biota. Buku 2. Editor oleh Hutagalung et al. Pusat Penelitian dan Pengembangan Oseanologi. Lembaga llmu Pengetahuan Indonesia. Jakarta.

Kelly, M. G. \& B. A. Whitton. 1989. Interspesific differences in $\mathrm{Zd}, \mathrm{Zn}$, and $\mathrm{Pb}$ accumulation by fresh water algae and bryophyta. Hydrobiologia. (175): $1-11$.

Nybaken, James W. 1992. Biologi laut. Gramedia. Jakarta.

Proteous, A. 1991. Dictionary of environmental science and technology. Open University Press. USA.

Pusat Penelitian Oseanografi. 2003. Laporan akhir. Dampak pasca banjir melalui tiga daerah aliran sungai terhadap kualitas air laut dan sumber daya perikanan di pantai utara Jakarta. Lembaga llmu Pengetahuan Indonesia. Jakarta

Puspasari. R. 2000. Peranan Fitoplankton dalam Mengurangi Kandungan Logam Berat $P b$ dalam Air Laut. Tesis. Institut Pertanian Bogor. Bogor. 
